Article

\title{
Spatiotemporal Organic Carbon Distribution in the Capo Peloro Lagoon (Sicily, Italy) in Relation to Environmentally Sustainable Approaches
}

\author{
Marilena Sanfilippo ${ }^{1}\left(\mathbb{D}\right.$, Marco Albano ${ }^{2, * \mathbb{D}}$, Antonio Manganaro ${ }^{2}$, Gioele Capillo ${ }^{3}$, Nunziacarla Spanò 4 (D) \\ and Serena Savoca 4
}

check for

updates

Citation: Sanfilippo, M.; Albano, M.; Manganaro, A.; Capillo, G.; Spanò,

N.; Savoca, S. Spatiotemporal Organic Carbon Distribution in the Capo Peloro Lagoon (Sicily, Italy) in Relation to Environmentally Sustainable Approaches. Water 2022, 14, 108. https://doi.org/10.3390/ w14010108

Academic Editor: Jun Yang

Received: 15 November 2021 Accepted: 29 December 2021

Published: 4 January 2022

Publisher's Note: MDPI stays neutral with regard to jurisdictional claims in published maps and institutional affiliations.

Copyright: (C) 2022 by the authors. Licensee MDPI, Basel, Switzerland. This article is an open access article distributed under the terms and conditions of the Creative Commons Attribution (CC BY) license (https:// creativecommons.org/licenses/by/ $4.0 /)$.
1 Stazione Zoologica Anton Dohrn (SZN), National Institute of Biology, Ecology and Marine Biotechnology, RIMAR Department, Sicily Marine Centre, Contrada Porticatello 29, 98167 Messina, Italy; marilena.sanfilippo@szn.it

2 Department of Chemical, Biological, Pharmaceutical and Environmental Sciences, University of Messina, Viale F. Stagno d'Alcontres 31, 98166 Messina, Italy; antonio.manganaro@unime.it

3 Department of Veterinary Sciences, University of Messina, Viale Annunziata, 98168 Messina, Italy; gioele.capillo@unime.it

4 Department of Biomedical, Dental and Morphological and Functional Imaging, University of Messina, Via Consolare Valeria 1, 98125 Messina, Italy; nunziacarla.spano@unime.it (N.S.); serena.savoca@unime.it (S.S.)

* Correspondence: marco.albano@unime.it

\begin{abstract}
Transitional water environments represent very ecologically interesting areas, which provide various ecosystem services, both concerning biodiversity protection and sustainable fruition of resources. In this way, the evaluation of total carbon and its components, chlorophyll, and chemical and physical parameters is of fundamental importance to deepen the dynamics of these peculiar natural areas. Commercial interests linked to the biological resources of these areas are often not well exploited in relation to their sustainability, due to lack of knowledge. In this study, we investigated the distribution of total organic carbon, chlorophyll, and other related physical and chemical parameters in the natural Lagoon of Capo Peloro (Eastern Sicily), to deepen the knowledge on the carbon equilibrium of these transitional basins. Collected data showed different trends for all parameters, mainly related to different seasons and water exchanges with sea. The influences of primary production sources and farmed molluscs were not negligible and deserve to be further investigated in the future. The results obtained reveal good margins for the possibility of environmentally sustainable exploitation of natural resources in both basins, but at the same time, there is a need for a more detailed knowledge of anthropogenic impacts on the area.
\end{abstract}

Keywords: aquaculture; carbon balance; coastal lagoon propierties; ecosystem properties; macroalgae cultivation; mollusc farming; primary production; sustainability; transitional waters

\section{Introduction}

Transitional water environments represent the natural, physical, and functional transition between terrestrial ecosystems and the sea [1-3]. These peculiar areas are often very productive and unique ecosystems around which many human commercial activities revolve $[2,4,5]$. Ecosystem services integrate ecology and economics issues to better understand the effects of human policies and impacts on both ecosystem function and human wellbeing [6-8]. Coastal lagoon water balances depend on the geomorphological characteristics and are highly influenced by the water exchanges with the sea, evaporation processes, rainfall, surface runoff, and groundwater input [9-11]. Data collection on chemical equilibria in these transitional ecosystems is of fundamental importance to understand the dynamics between abiotic and biotic compartments. [5,12]. 
Among the chemical elements present in the aquatic environment, carbon certainly plays a major role in the ecosystems balance [13]. Carbon can be present in water both in inorganic form (carbonates, bicarbonates, and carbon dioxide) and in organic compounds that are distributed between dissolved and suspended phases [14].

The total carbon (TC) present in water results from the sum of the total inorganic carbon (TIC) and the organic carbon (TOC) present in the two phases [15]. Dissolved organic carbon (DOC) represents the organic fraction of carbon that passes through a $0.45 \mu \mathrm{m}$ filter membrane [16-18], while suspended or particulate organic carbon (POC) represents the fraction retained by the membrane $[19,20]$. The amount of these two fractions gives the total organic carbon (TOC) [21]. Dissolved Inorganic Carbon (DIC) is the inorganic fraction as studied by St. Laurent [22]. Finally, volatile organic carbon (VOC) is the fraction of carbon that can be analytically removed from the water sample by gas stripping under certain conditions [23]. NPOC (not purgeable organic carbon) refers to the nonvolatile fraction of organic carbon [24]. All these carbon fractions play a vital role as a vector of matter and energy in the lagoon ecosystems, both for the organic compart and the sedimentological one $[2,4,25,26]$.

Capo Peloro Lagoon is an ecologically interesting area constituted by two main basins (commonly named Ganzirri Lagoon and Faro Lagoon) connected by some channels between them and with the surrounding sea $[27,28]$. This transitional environment has been studied from many different points of view from ancient times to the present day, due to its natural and commercial relevance. The research carried out has focused on purely geomorphological aspects [29], or chemical, physical, and biological aspects [30-32], the distribution of organic compounds, metals, electrolytes, and PCBs in water and organisms [28,33], the presence of bivalve molluscs and bioenergetic properties [34,35], the microbial structures present [36], and some other publications on similar aspects, but there are no specific studies regarding organic carbon distribution and its environmental implications in the examined area. Considering the environmental importance of natural organisms present in this lagoon, the commercial importance of the biological resources farmed in this area [4,9,37], and the possible correlation with other similar transitional areas worldwide distributed [38-40], deepening these aspects to enrich the existing database for these environments is essential. Moreover, enhancing the knowledge of ecological equilibria that regulate the sustainability of protected areas, especially the more anthropized areas, is necessary both for commercial and biological purposes [41,42].

Hence, the aims of this research were (i) to investigate the distribution of total organic carbon in the natural Lagoon of Capo Peloro (Messina, Eastern Sicily) to deepen the knowledge on the carbon equilibrium of these transitional basins; (ii) to collect new data on the chlorophyll and other chemical and physical parameters to better understand the dynamics that regulate these basins; and (iii) to provide more ideas for future studies aimed to better manage the area and ensure a more profitable and sustainable use of its resources, starting from the limitations encountered during this research.

\section{Materials and Methods}

\subsection{Study Area}

The study was carried out in two brackish ponds, located close to the Capo Peloro area (Messina, Italy), in the north-eastern corner of Sicily ( $\left.38^{\circ} 15^{\prime} 57^{\prime \prime} \mathrm{N}, 15^{\circ} 37^{\prime} 50^{\prime \prime} \mathrm{E}\right)$, between the Tyrrhenian and the Ionian Sea [27,43-45]. This system consists of two basins, Ganzirri and Faro, communicating each other by the Margi Channel [46,47]. This area is particularly important from an ecological point of view also for the close correlation with extremely peculiar and characteristic habitats of the Strait of Messina area [6,10,48].

Ganzirri Lagoon, whose formation can be traced back between 3000 and 2500 BC, is a brackish coastal basin; it covers a 34 ha area (maximum depth: $7 \mathrm{~m}$; water volume: $106 \mathrm{~m}^{3}$ ). It communicates with the Straits of Messina through Carmine Channel and with Faro Lagoon through Margi Channel. It has the appearance of a long $(1670 \mathrm{~m})$ and narrow (on average $\sim 200 \mathrm{~m}$ ) stream tube parallel to the coast. 
Faro is a small meromictic marine coastal lagoon [12]. It covers a 26 ha area and has a nearly circular shape with a $\sim 500 \mathrm{~m}$ diameter. This basin has an average depth of about $3 \mathrm{~m}$, while in its central part it reaches a depth of $30 \mathrm{~m}$. It communicates with the Tyrrhenian Sea through an artificial Channel (commonly named English Channel) that is open only sporadically during summer and continuously with the Straits of Messina through the Faro Channel [35]. The Faro Lagoon is characterized by the presence of hydrogen sulphide $\left(\mathrm{H}_{2} \mathrm{~S}\right)$ in the hypolimnion and a brownish water layer at the chemocline (at about $10 \mathrm{~m}$ depth) colonized by dense populations of phototrophic sulphur bacteria [30]. In meromictic basins, vertical gradients of nutrients also determine a vertical zonation of the planktonic microbial community, with consequences on the biogeochemical cycling of nutrients and the anaerobic decomposition of organic matter [36].

Due to its variable exchanges with the sea, underground springs, seasonal climatic conditions, and also surface runoff [49], the Capo Peloro Lagoon is characterized by large fluctuations in chemical and physical variables, especially salinity, temperature, and dissolved oxygen, mainly in the Faro Lagoon [50].

The Lagoons of Ganzirri and Faro are "Heritage of ethno-anthropological interest" (declaratory measure 1342/88) since they are seats of traditional working and productive activities related to shellfish farming (mussels and tellinas). Capo Peloro is also a Natural Reserve, established by the Sicilian Region with D.A. 21/6/01, as well as Site of Community Importance (SIC) according to Directive 92/43/CEE and Special Protection Zone (ZPS) according to Directive 79/409/CEE.

The Ganzirri Lagoon was historically used for shellfish culture until 1995, after which, because of heavy pollution and contamination by pathogenic prokaryotes, activity ceased. The Faro Lagoon, however, is still largely exploited for bivalve rearing and cultivation (mainly Mytilus galloprovincialis), with an estimated mean annual cultivated biomass of $\sim 300$ t [35].

\subsection{Sampling Design}

Sampling was carried out between May 2010 and March 2011 in the natural reserve of Capo Peloro, (Eastern Sicily; $38^{\circ} 15^{\prime} 57^{\prime \prime} \mathrm{N} ; 5^{\circ} 37^{\prime} 50^{\prime \prime} \mathrm{E}$ ) (Figure 1). This area is constituted by the Ganzirri Lagoon (G1, G2 sampling points) and the Faro Lagoon (F1, F2, F3 sampling points), that are connected by the Margi Channel. Samplings were carried out also in the surrounding Tyrrhenian Sea (M1, M2 sampling point) and Strait of Messina (M3) to evaluate the enrichment compared to the neighboring properly marine environment (Figure 1). The sampling points inside the lagoons were chosen based on both previous historical sampling surveys and as representative of the two areas; the control points (sea) were chosen near the opening of the channels of the two lagoons. To better compare the data and make the samples more representative, all the samples were collected at the water surface. In fact, being relatively shallow basins, variable in time especially in the areas near the connection channels, sampling on the bottom would have led to a comparison of data from different depths. In addition, the stratification of water found in these areas is not to be considered significant (except for the deep anoxic zone of Lagoon Faro), so the surface samples can be considered sufficiently representative. 


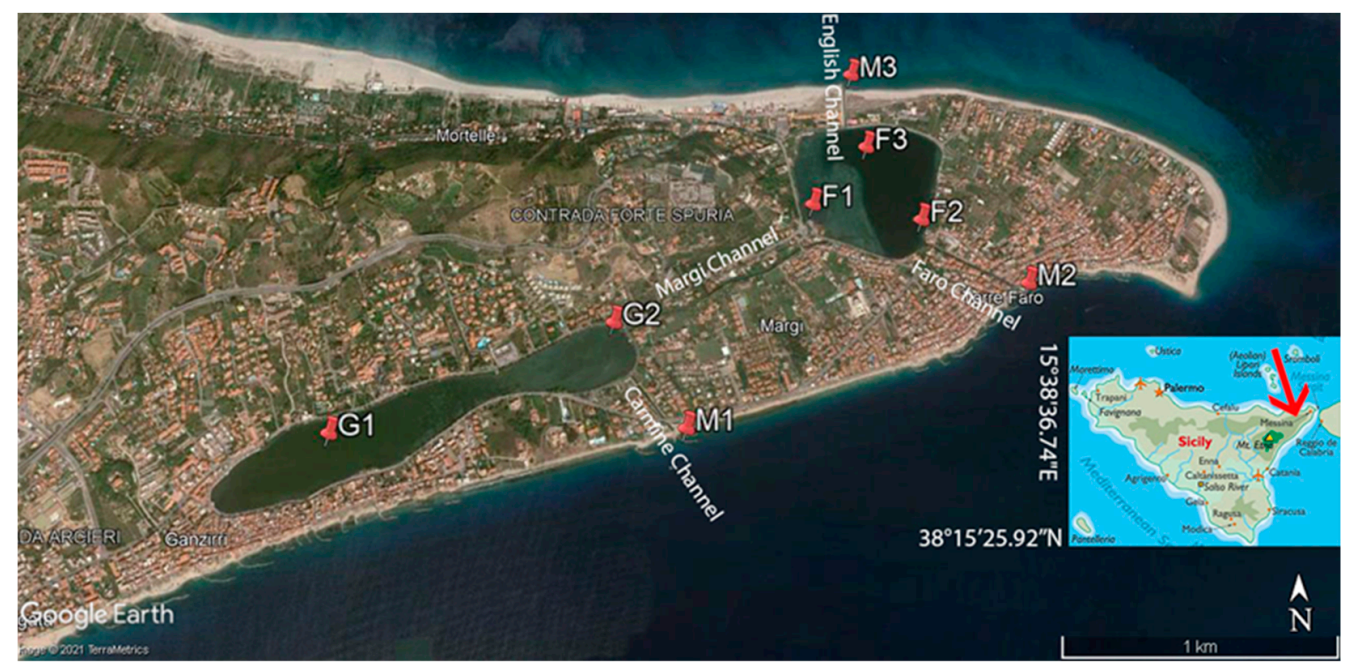

Figure 1. Study area with sampling points and connection channel.

Water samples were collected three times per season (monthly) in triplicate from the stations reported in Figure 1. As shown in Figure 1, two stations are located in the Ganzirri Lagoon: G1 ( $\left.38^{\circ} 15^{\prime} 35.19^{\prime \prime} \mathrm{N} ; 15^{\circ} 36^{\prime} 46.66^{\prime \prime} \mathrm{E}\right)$ and G2 $\left(38^{\circ} 15^{\prime} 48.50^{\prime \prime} \mathrm{N} ; 15^{\circ} 37^{\prime} 30.93^{\prime \prime} \mathrm{E}\right)$, representative of the two sub-basins of the lagoon, and three stations in the Faro Lagoon: $\mathrm{F} 1\left(38^{\circ} 16^{\prime} 3.56^{\prime \prime} \mathrm{N} ; 15^{\circ} 38^{\prime} 3.37^{\prime \prime} \mathrm{E}\right), \mathrm{F} 2\left(38^{\circ} 16^{\prime} 1.28^{\prime \prime} \mathrm{N} ; 15^{\circ} 38^{\prime} 20.79^{\prime \prime} \mathrm{E}\right)$, and F3 ( $38^{\circ} 16^{\prime} 11.21^{\prime \prime} \mathrm{N}$; $15^{\circ} 38^{\prime} 12.52^{\prime \prime} \mathrm{E}$. In the same manner as the lagoon, the control samples at sea were all collected at the surface for uniformity and to better compare the data: $\mathrm{M} 1\left(38^{\circ} 15^{\prime} 35.10^{\prime \prime} \mathrm{N}\right.$; $\left.15^{\circ} 37^{\prime} 42.15^{\prime \prime} \mathrm{E}\right), \mathrm{M} 2$ ( $\left.38^{\circ} 15^{\prime} 52.72^{\prime \prime} \mathrm{N} ; 1^{\circ} 38^{\prime} 37.24^{\prime \prime} \mathrm{E}\right)$, and M3 (38 $\left.16^{\prime} 21.29^{\prime \prime} \mathrm{N} ; 5^{\circ} 38^{\prime} 10.65^{\prime \prime} \mathrm{E}\right)$.

The sampling was carried out with a Niskin bottle previously acid-soaked (ca. 1\% AR grade $\mathrm{HCl}$ ). Dissolved oxygen, conductivity, salinity, and temperature were recorded with a YSI 85 multiparameter probe, while $\mathrm{pH}$ measurements were made using a $\mathrm{pH} 110 \mathrm{XS}$ Instruments $\mathrm{pH}$ meter. The oxygen sensor was calibrated using the Winkler method [51]. Water clarity measurements were made with the Secchi Disk (m). Water samples were collected in plastic containers appropriately treated with acid wash and subsequently rinsed with distilled water for chlorophyll analyses; samples for carbon determinations were collected directly into glass vials previously washed in $20 \%$ hydrochloric acid; all samples were collected in duplicate.

\subsection{Laboratory Studies}

TC and NPOC samples were analyzed using a TOC-VCS Analyzer (Shimadzu Europa $\mathrm{GmbH}$ ). Potassium hydrogen phthalate was used as a standard for TC and NPOC analysis (calibration curve 10-30-50-100 mg/L).

Photosynthetic pigments and dissolved oxygen were analyzed previous filtration of the samples by APAT-CNR/IRSA [52]. The spectrophotometric determinations were conducted by Shimadzu UV-1800. All samples were processed and analyzed at the laboratory of aquatic chemistry, at the University of Messina laboratory.

All the data are presented as the mean \pm standard deviation (SD) $(n=3)$. One-way analysis of variance (ANOVA) followed by Tukey's test were performed to highlight any significant difference in selected variables (TC, NPOC, and CHLa) across sampling sites (Faro, Ganzirri, Sea). The significance level was set at $p<0.05$. Prior to the analysis, the assumptions of normality and homoscedasticity were checked by the Shapiro-Wilk test and Levene test, respectively. All statistical analyses were performed using Prism V.8.2.1 (Graphpad Software Ltd., La Jolla, CA 92037, USA).

\section{Results}

Key water chemistry and physical parameters were investigated along the sampling stations with carbon parameters. Seasonal average trends are shown in Table 1. 
Table 1. Average values \pm standard deviation $(n=3)$ of temperature, $\mathrm{pH}$, salinity, Total Carbon (TC), Not Purgeable Organic Carbon (NPOC), and Chlorophyll (CHLa) in Ganzirri and Faro Lagoons and in control points.

\begin{tabular}{|c|c|c|c|c|c|c|c|c|}
\hline & & $\mathrm{T}^{\circ} \mathrm{C}$ & $\mathrm{pH}$ & Sal (PSU) & $\mathrm{O}_{2}(\mathrm{sat} \%)$ & TC (mg/L) & $\begin{array}{l}\text { NPOC } \\
(\mathrm{mg} / \mathrm{L})\end{array}$ & $\begin{array}{c}\text { CHLa } \\
(\mathrm{mg} / \mathrm{L})\end{array}$ \\
\hline \multirow{4}{*}{ Ganzirri } & Spring & $24.23 \pm 1.72$ & $8.50 \pm 0.04$ & $29.87 \pm 2.23$ & $140.81 \pm 5.37$ & $27.05 \pm 4.58$ & $6.37 \pm 1.38$ & $7.15 \pm 4.44$ \\
\hline & Summer & $27.53 \pm 0.06$ & $8.37 \pm 0.06$ & $35.10 \pm 0.44$ & $137.98 \pm 7.05$ & $27.05 \pm 4.58$ & $7.68 \pm 1.52$ & $8.06 \pm 4.17$ \\
\hline & Autumn & $14.03 \pm 1.27$ & $8.05 \pm 0.03$ & $31.17 \pm 0.29$ & $104.37 \pm 10.53$ & $28.04 \pm 1.31$ & $4.03 \pm 0.26$ & $2.91 \pm 0.84$ \\
\hline & Winter & $14.83 \pm 2.35$ & $8.05 \pm 0.06$ & $26.93 \pm 5.61$ & $102.33 \pm 22.24$ & $29.02 \pm 5.95$ & $3.63 \pm 0.11$ & $3.83 \pm 5.77$ \\
\hline \multirow{4}{*}{ Faro } & Spring & $23.26 \pm 3.13$ & $8.04 \pm 0.10$ & $34.06 \pm 1.34$ & $107.66 \pm 24.79$ & $21.66 \pm 2.68$ & $3.55 \pm 0.97$ & $4.54 \pm 2.05$ \\
\hline & Summer & $26.60 \pm 0.64$ & $8.12 \pm 0.04$ & $36.58 \pm 0.36$ & $104.35 \pm 13.85$ & $20.24 \pm 0.69$ & $2.67 \pm 0.38$ & $1.33 \pm 0.57$ \\
\hline & Autumn & $13.18 \pm 0.90$ & $7.86 \pm 0.07$ & $32.36 \pm 3.51$ & $82.10 \pm 10.09$ & $35.43 \pm 3.37$ & $5.10 \pm 3.60$ & $1.71 \pm 0.78$ \\
\hline & Winter & $14.32 \pm 0.93$ & $8.03 \pm 0.17$ & $32.88 \pm 1.59$ & $93.68 \pm 36.80$ & $16.34 \pm 1.13$ & $2.76 \pm 0.41$ & $0.41 \pm 0.33$ \\
\hline \multirow{4}{*}{ Sea } & Spring & $20.57 \pm 2.06$ & $8.28 \pm 0.09$ & $36.33 \pm 0.50$ & $113.25 \pm 14.05$ & $22.83 \pm 2.43$ & $4.13 \pm 2.28$ & $0.32 \pm 0.12$ \\
\hline & Summer & $25.03 \pm 0.15$ & $8.24 \pm 0.02$ & $36.93 \pm 0.31$ & $105.98 \pm 3.97$ & $25.12 \pm 2.01$ & $5.95 \pm 1.37$ & $0.43 \pm 0.31$ \\
\hline & Autumn & $15.17 \pm 0.95$ & $8.12 \pm 0.01$ & $35.47 \pm 0.98$ & $96.37 \pm 2.82$ & $34.07 \pm 2.55$ & $3.22 \pm 0.84$ & $0.48 \pm 0.53$ \\
\hline & Winter & $15.00 \pm 0.46$ & $8.19 \pm 0.02$ & $36.67 \pm 0.15$ & $109.22 \pm 8.19$ & $32.56 \pm 1.64$ & $1.71 \pm 0.48$ & $0.06 \pm 0.05$ \\
\hline
\end{tabular}

In Ganzirri Lagoon, the temperature varied from a minimum of $14.03{ }^{\circ} \mathrm{C}$ (autumn) to a maximum of $27.53^{\circ} \mathrm{C}$ (summer), $\mathrm{pH}$ fluctuated in the range 8.05 (autumn)-8.50 (spring); salinity ranged from 26.90 PSU (winter) to 35.10 PSU (summer), while oxygen saturation was always above 100\% (102.33\% minimum during winter and $140.81 \%$ maximum in spring). In Faro Lagoon, temperature varied from a minimum of $13.18{ }^{\circ} \mathrm{C}$ (autumn) to a maximum of $26.60{ }^{\circ} \mathrm{C}$ (summer), $\mathrm{pH}$ fluctuated in the range 7.86 (autumn)-8.12 (summer); salinity ranged from 32.36 PSU (autumn) to 36.58 PSU (summer), while oxygen saturation varied from a minimum of $82.10 \%$ during autumn and $107.66 \%$ of maximum in spring. Data on the T/S trend are shown in Figure 2.
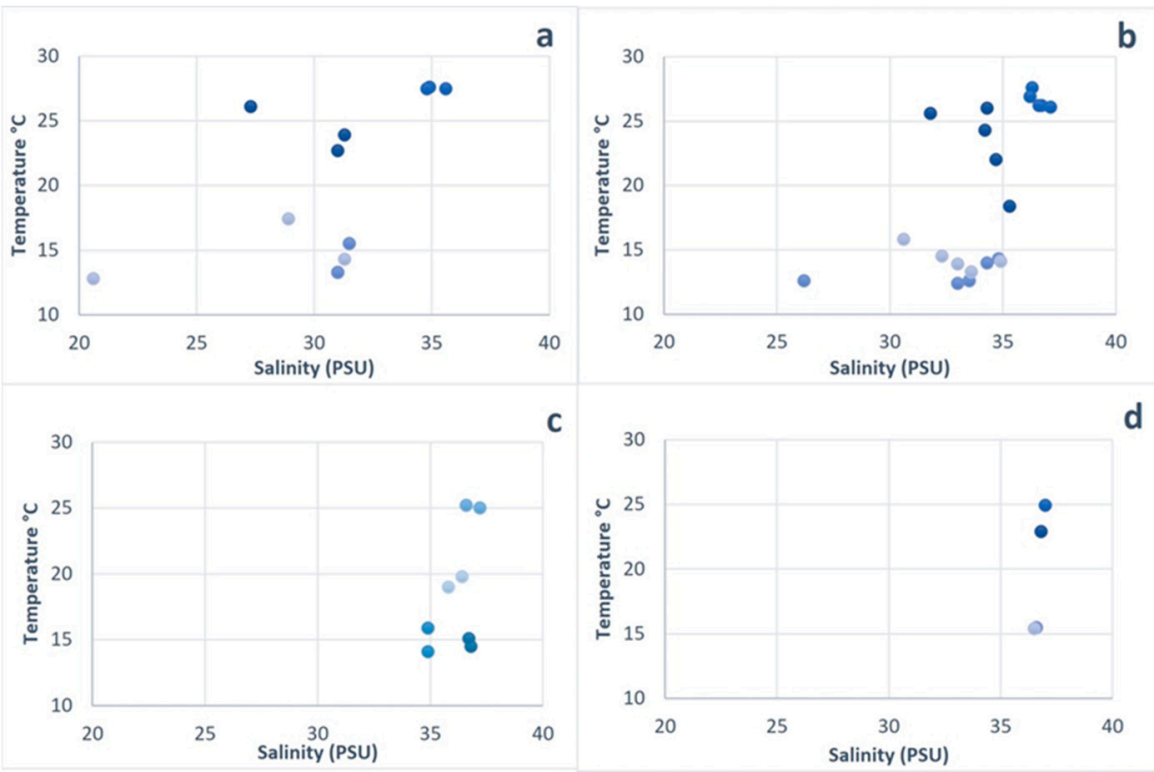

Figure 2. T/S diagrams of Ganzirri Lagoon (a), Faro Lagoon (b), Tyrrhenian Sea (c), and Strait of Messina (d).

Figure 3 represents the combined trend of percent oxygen saturation and $\mathrm{pH}$ during a four-season sampling period; the disparities between the different environments can be clearly seen in this case. 


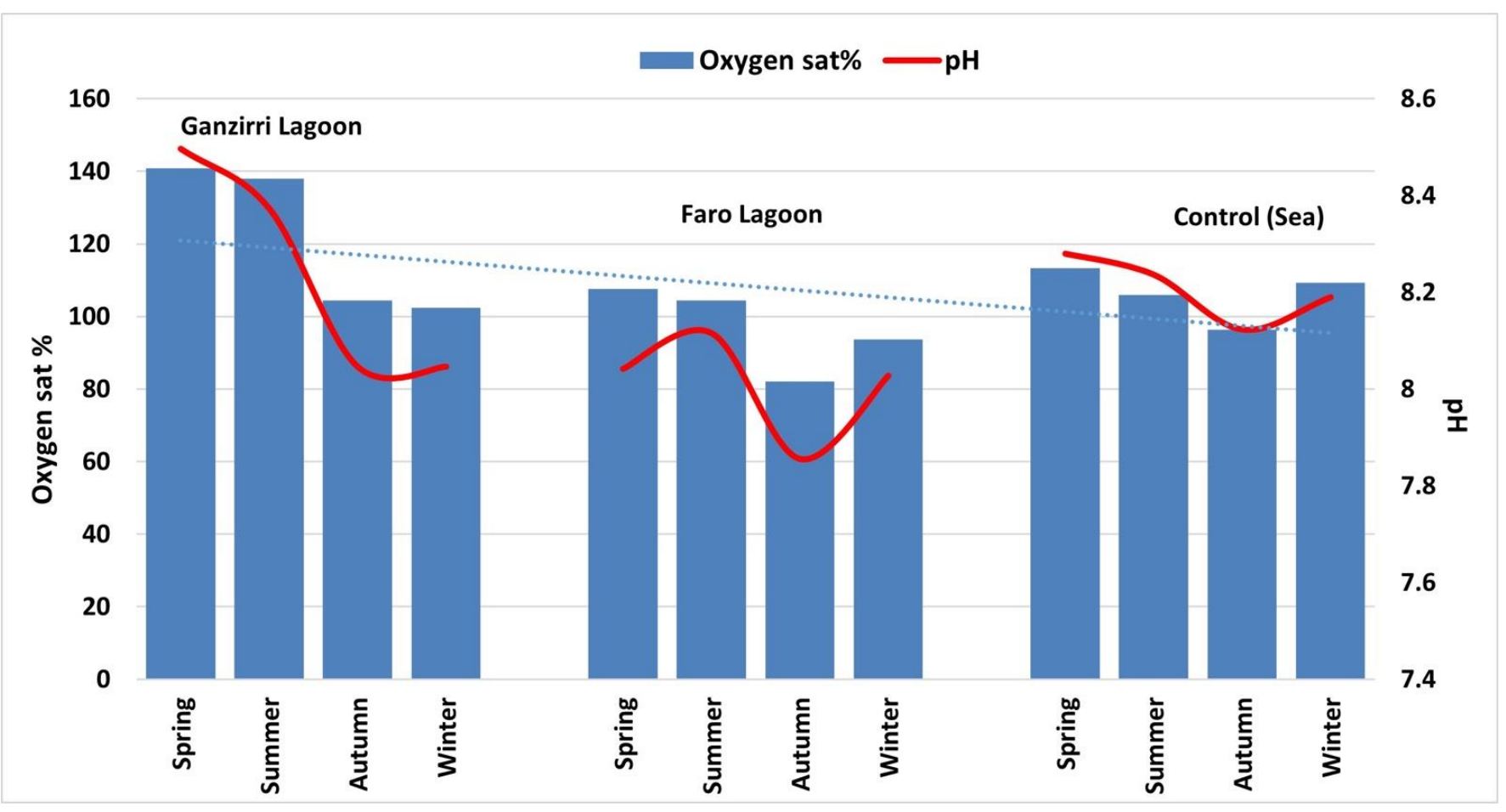

Figure 3. Mean values of oxygen percentage saturation (Oxygen sat $\%$ ) and $\mathrm{pH}$ in the two Lagoons and in the control (sea) during the sampling period (March 2010-May 2011). $(n=3)$.

The trend of organic carbon showed, especially during the summer, a substantial differentiation between the two lagoon environments, with a greater abundance of NPOC in the Lagoon of Ganzirri (difference of about $4 \mathrm{mg} / \mathrm{L}$ ), as reported in Figure 4.

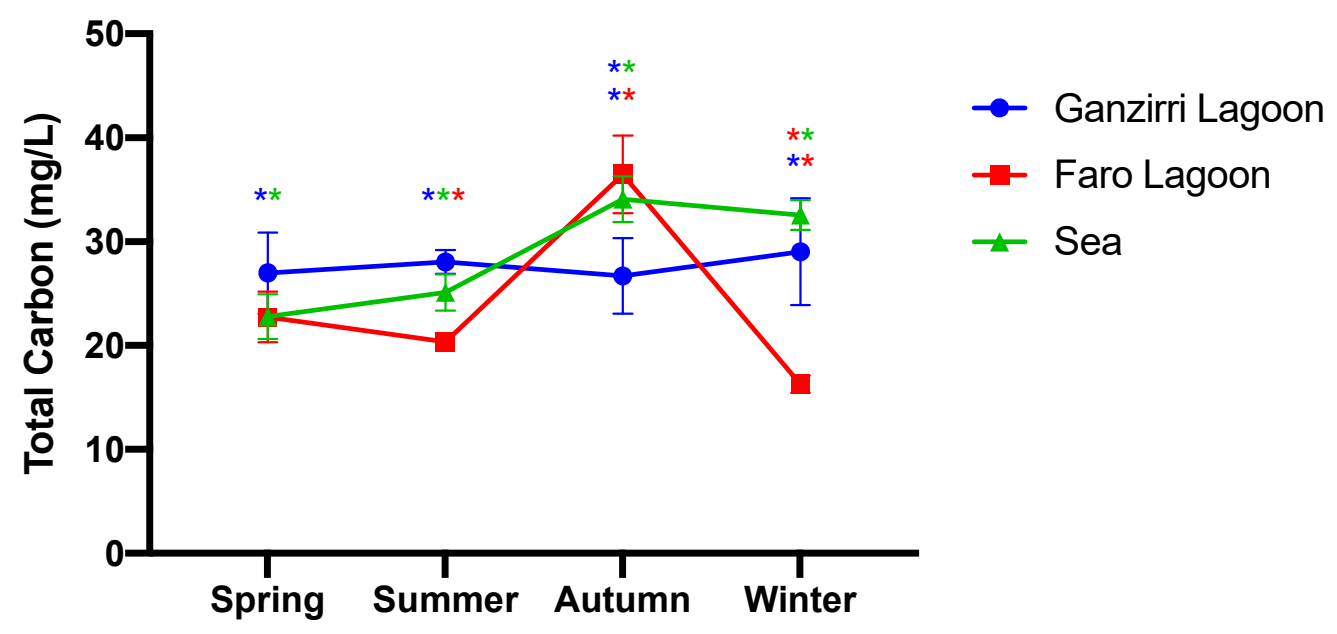

Figure 4. Total Carbon (TC) trends during the sampling period. Stars represent significant differences between the sampling sites. Differences were considered significant when $p<0.05$. $(n=3)$.

The trend of Total Carbon (TC) in the two brackish lagoons showed a decline during the winter in Faro Lagoon and a decrease during the autumn in Ganzirri Lagoon, in contrast to the general trend. One-way analysis of variance (ANOVA) followed by Tukey's test highlighted that in the autumn, TC was significantly different between Ganzirri and Faro Lagoon ( $p=0.0073$ ) and Ganzirri and Sea. During the winter, the TC was significantly different between the lagoons $(p<0.001)$ and between Faro and the sea $(p<0.001)$. During the spring, TC showed a significant difference between Ganzirri and the sea $(p=0.0302)$; however, no differences were detected between the lagoons. During the summer, TC was 
significantly different across all stations analyzed $(p<0.001)$ as well as NPOC and CHLa. The trends related to the sea samples have the same seasonal patterns.

The Organic Carbon (NPOC) trend was similar for all environments considered apart from the Faro Lagoon that had a decline in values during the summer (Figure 5).

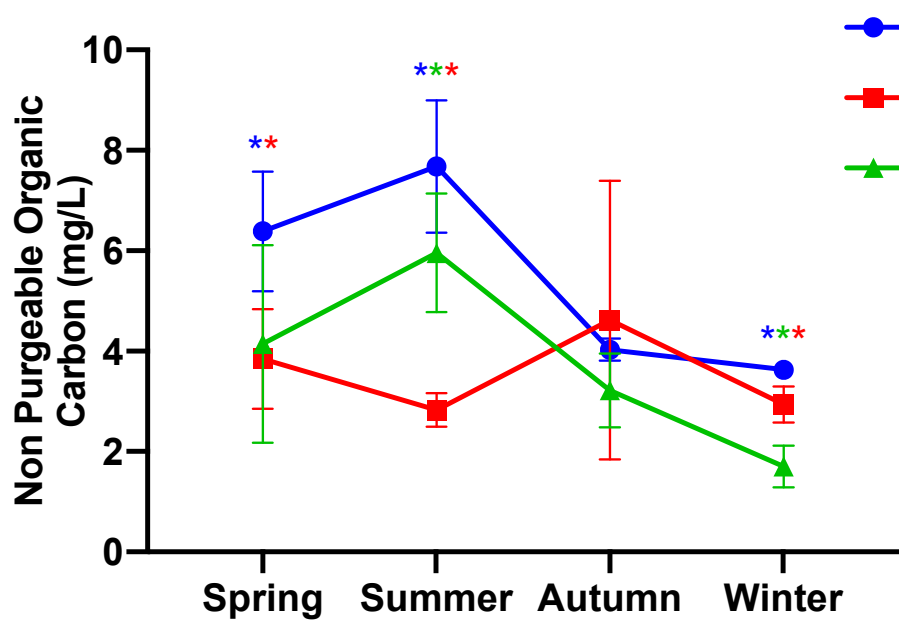

- Ganzirri Lagoon

t- Faro Lagoon Sea

Figure 5. Non Purgeable Organic Carbon (NPOC) trends during the sampling period. Stars represent significant differences between the sampling sites. Differences were considered significant when $p<0.05$. $(n=3)$.

During winter, the NPOC was different between all stations $(p<0.05)$. In spring, a different trend was observed for the NPOC between the lagoons $(p=0.0124)$. While in summer, the NPOC did not show any significant differences between the stations analyzed $(p>0.05)$.

By relating the trend of organic carbon (NPOC) with CHLa (Figure 6), we see that there is a high degree of correlation $(\mathrm{R})$ in both Lagoons, greater for Ganzirri. During the winter, CHLa showed significant differences only between the lagoons, and between Ganzirri and the sea. In spring, CHLa was significantly different between Ganzirri and the sea and Faro and the sea, but no differences were observed between lagoons $(p>0.05)$. Finally, in summer, CHLa was different across all the three stations.

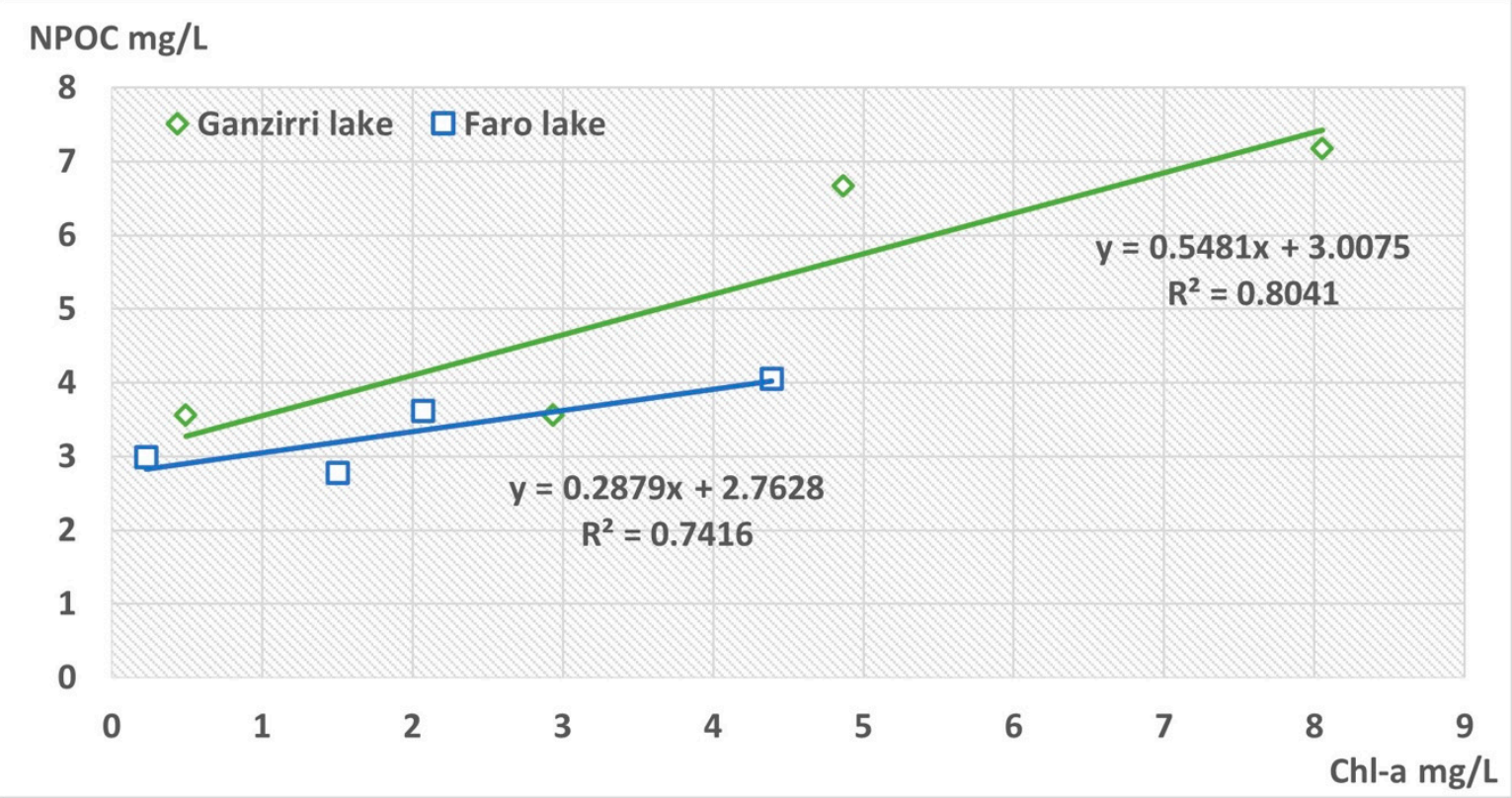

Figure 6. Non Purgeable Organic Carbon (NPOC)/Chlorophill a (CHLa) ratio in the Lagoons of Faro and Ganzirri and their correlation (R). 


\section{Discussion}

Transitional waters are historically considered to be biologically interesting environments for biodiversity wealth and often the presence of endemism and native species $[34,53]$. In European countries, the protection and maintenance of the natural balance of aquatic ecosystems is regulated by the Water Framework Directive (WFD) [54]. Though the integration of biological element data such as fish fauna, benthic organisms (invertebrate and vegetal) and phytoplankton, together with hydromorphology and physical and chemical parameters (including nutrient elements), the ecological status of aquatic ecosystems can be assessed [55]. Understanding the distribution of nutrient elements as carbon is, therefore, even more important in ecosystems with very variable balances such as transitional lagoons [56]. Mediterranean transitional ecosystems are mainly coastal areas of shallow water, often partially isolated from the surrounding sea by sandbanks and shingle, less frequently by rocks $[57,58]$. Moreover, the correlations between Mediterranean brackish areas are important for the research in the field, as they represent very peculiar areas, rare, and characterized by fluctuant balances difficult to understand without comparisons [59-61]. Economics interests involved in these kinds of areas represent an additional boost to the better understanding of the dynamics that regulate them [39,62]. Capo Peloro Lagoon represents, with its two basins and their connection channels, an important area for the human communities that live around it, from ecological, historical, and commercial points of view $[27,28,63]$. Despite the interconnections between human activities and the natural environment, due also to the proximity of the inhabited areas to the lagoon, studies in this area have focused increasingly on the organisms that inhabit this ecosystem and rarely on the balances that regulate it $[28,31,64]$. No study has ever been conducted to investigate the distribution of carbon in the study area.

Our T/S diagrams reported in Figure 2, show differences during the seasonal evolution, between the sampling stations examined, in terms of temperature range and salinity. However, variations in temperature and salinity were generally small between control and lagoon's samples, confirming the marine origin of the two basins of Faro and Ganzirri, as already reported by other authors [27,65-67]. Particularly, our data showed that salinity was higher in the Faro Lagoon than the Ganzirri Lagoon; this was probably due to the Ganzirri Lagoon's greater distance from the sea that caused a major isolation of this basin as reported by Yan et al. for Saroma Lagoon [68] and by Shadrin et al. for Sivash Bay [67]. The smaller extent of the Faro basin and its pseudo-circular shape, combined with the presence of constant communication throughout the year with the Strait of Messina through the Faro Channel, make the water exchange of this basin more effective. This was also accentuated by the opening during the critical summer season of the English Channel, which communicating directly with the Tyrrhenian Sea increases the water exchange. This practice is in fact usually carried out by shellfish farms operating in the Faro Lagoon to avoid water overheating events or the creation of anoxia zones during the warm season.

It was evident that the control stations (sea) showed differences in salinity and temperature related to the diversity of the two seas (Ionian and Tyrrhenian), with the Tyrrhenian showing higher salinity and slightly lower temperature [12,66]. The temperature trend in the two basins rather clearly reflected the seasonal trend, with higher values in the spring-summer period and lower values in the autumn-winter period as reported by Kjerfve [69] for this kind of basin.

The salinity trend was higher in all seasons for the Faro Lagoon, which shows the character of a purely brackish lagoon reported by other authors for similar basins $[59,70,71]$. The lower values recorded in this case for the Ganzirri Lagoon, confirmed the greater isolation of this basin and, therefore, the greater influence on the salinity of the rainwater inputs, especially between autumn and spring that led to a minor salinity compared to Faro Lagoon and control (sea). The influence of rainwater on surface water was already reported by other authors as a common process in different aquatic ecosystem [72-74].

As reported in Figure 3, the Ganzirri Lagoon showed the highest values of oxygen, in some periods exceeding the saturation value (particularly in spring and summer seasons), 
with a maximum value around $140 \%$, mainly due to the presence of periodical algal blooms and the shallow depth of this basin that contribute to amplifying this phenomenon as reported by Giuffrè [31]. Faro Lagoon showed a minor level of dissolved oxygen, in some cases under the saturation value, ranging between $80 \%$ and $110 \%$. This lower trend was attributable to the massive presence of the shellfish farm as reported by Rinaldi et al. [34] and Manganaro et al. [35]. The control point showed intermediate values between the two lagoon environments, demonstrating the influence of the major proximity between the sea and Faro Lagoon that influenced these trends [71,75]. Indeed, the values of the Faro Lagoon were more similar to the control compared to the Ganzirri Lagoon, as expected considering the higher water exchange of this basin. The influence on this value of shellfish farming is evident since this value was less than in the control, due to the use of dissolved oxygen in water by farmed molluscs, as reported by other authors for similar basins [76,77].

The obtained $\mathrm{pH}$ data showed that this parameter reached higher values in the Ganzirri Lagoon (mean value 8.4) compared to the Faro Lagoon (mean value 8). Even in this case, this value could be linked to the minor water exchange between the Ganzirri basin and the sea, compared to the Faro Lagoon. The higher evaporation rate due to the larger surface area of Ganzirri Lagoon, combined with the lower water exchange, can lead to the accumulation of ions that influence this trend [78]. However, the influence on this parameter of other intrinsic characteristics of the two areas under investigation, as well as of the acidification of water, factors which merit further studies to be better understood, cannot be excluded [79].

The TC seasonal trend observed was mainly related to the dynamic presence of primary consumers as cultured shellfish, which are present in Faro Lagoon $[31,34,35]$. Indeed, the decline of TC value observed during the winter in Faro Lagoon was attributable to the major quantity of housed commercial shellfish, mainly Mytilus galloprovincialis, that affect the equilibrium of TC in brackish environments with a direct influence on the carbon budget of coastal marine environments as reported by Rodhoouse and Roden [80], and more in general on TSM as reported by Sarà and Mazzola [81]. Regarding the value of TC in the Ganzirri Lagoon, we detected a decrease in autumn in contrast to the general trend of the studied area. This was mainly attributable to the life cycle of traditional clam farming in this basin, such as Cerastoderma glaucum, Polititapes aureus, and Ruditapes decussatus [35]. Indeed, autumn is the most important season for the mass growing of these organisms, that consequently contribute to the TC value decrease [34,35]. A partial contribution to the TC trend in these basins was attributable to macroalgae, that particularly in Ganzirri Lagoon are seasonally well represented, mainly by Gracilaria gracilis $[64,66]$. The annual cycle of these vegetal organisms involves two mass growing seasons, corresponding in these environments to spring and autumn, and even in this case with our registered TC decrease $[82,83]$. As reported by Buapet et al. [84], in coastal and shallow areas macroalgae can affect the TC balance with their photosynthetic activity.

The NPOC trend showed more variability among sampling stations during winter and during the summer period. These variations probably resulted, even in this case, from the presence of farming shellfish for commercial purposes and natural macroalgae, that alters the balance of the organic substances involved in their metabolic processes $[35,81,84]$.

The CHLa value range showed an interesting trend across winter and spring between the two basins, that indicates that the organic carbon comes mainly from the phytoplanktonic organisms present in this area [12,31]. The highest stable presence of phytoplanktonic organisms in Ganzirri Lagoon explains the increased CHLa value during the winter compared to the Faro Lagoon. During the spring, the common bloom of phytoplanktonic organisms lead to a reduction in the difference in CHLa values between the two basins. The influence on this value by phytoplanktonic organisms was already reported by several authors in estuarine and coastal areas [85-87]. Moreover, in the Faro Lagoon, the correlation between NPOC and CHLa $(R=0.74)$ can be linked to the presence of mussels and to their influence on the autotrophic equilibrium with a bottom-up-like control on primary consumers communities as reported by Frojan et al. [88]. 
Deepening the trophic potential of the area under investigation, could lead to defining as many as possible sustainable activities, promoting the maintenance of equilibria among the farmed organisms and the natural environment and to increase their use as experimental model organisms [89-94].

\section{Conclusions}

The data obtained in this study and the subsequent elaboration allowed us: (i) to increase the data bank related to the cycle of organic carbon and its distribution in the two brackish environments of Capo Peloro lagoon, which was poor in this regard; (ii) to a better understanding, through the analysis of the data collected on the chemical and physical characteristics, of the chemical and biological dynamics that regulate these basins, linked both to their morphology and origins, as well as the connections between them and with the surrounding seas; (iii) to open up new opportunities for environmentally sustainable exploitation of natural resources already present in Capo Peloro lagoons, such as the maintenance of mussel farming, the recovery of an old tradition of clam aquaculture, and also for cultivation of macroalgal species of biotechnological interest, such as Gracilaria gracilis $[27,34,64]$.

This study is to be considered as a first contribution to the carbon dynamics of this aquatic ecosystem, as it is limited to a time-space survey based on surface samples. Future studies are required to deepen a nonnegligible aspect on the carbon balance of this area, which emerged during this survey, represented by occasional anthropogenic inputs of water. Moreover, it would be important to update and quantify the phytoplanktonic communities currently present in these environments, since the data available in this regard are rather ancient [31]. In addition, a better mapping of the study area with tools (e.g., GIS mapping software) could help to better integrate the aquatic ecosystem data to the surrounding urban-terrestrial area.

Author Contributions: Conceptualization, M.S. and G.C.; methodology, M.S.; validation, M.S.; formal analysis, M.S.; investigation, M.S.; data curation, S.S.; writing—original draft preparation, M.S. and M.A.; writing-review and editing, M.S. and M.A.; supervision, N.S. and A.M. All authors have read and agreed to the published version of the manuscript.

Funding: This research received no external funding.

Institutional Review Board Statement: Not applicable.

Informed Consent Statement: Not applicable.

Acknowledgments: The authors acknowledge Sig. Giovanni Maio of Messina University for the support during sampling operations.

Conflicts of Interest: The authors declare no conflict of interest.

\section{References}

1. Pérez-Ruzafa, A.; Marcos, C.; Pérez-Ruzafa, I.M.; Pérez-Marcos, M. Coastal lagoons: “Transitional ecosystems" between transitional and coastal waters. J. Coast. Conserv. 2011, 15, 369-392. [CrossRef]

2. Basset, A.; Sabetta, L.; Fonnesu, A.; Mouillot, D.; Do Chi, T.; Viaroli, P.; Giordani, G.; Reizopoulou, S.; Abbiati, M.; Carrada, G.C. Typology in Mediterranean transitional waters: New challenges and perspectives. Aquat. Conserv. Mar. Freshw. Ecosyst. 2006, 16, 441-455. [CrossRef]

3. Pérez-Ruzafa, A.; De Pascalis, F.; Ghezzo, M.; Quispe-Becerra, J.I.; Hernández-García, R.; Muñoz, I.; Vergara, C.; Pérez-Ruzafa, I.M.; Umgiesser, G.; Marcos, C. Connectivity between coastal lagoons and sea: Asymmetrical effects on assemblages' and populations' structure. Estuar. Coast. Shelf Sci. 2019, 216, 171-186. [CrossRef]

4. Padedda, B.M.; Pulina, S.; Satta, C.T.; Lugliè, A.; Magni, P. Eutrophication and Nutrient Fluxes in Mediterranean Coastal Lagoons. Encycl. Water. 2019, 1-16. [CrossRef]

5. McLusky, D.S.; Elliott, M. Transitional waters: A new approach, semantics or just muddying the waters? Estuar. Coast. Shelf Sci. 2007, 71, 359-363. [CrossRef]

6. Capillo, G.; Panarello, G.; Savoca, S.; Sanfilippo, M.; Albano, M.; Volsi, R.L.; Consolo, G.; Spanò, N. Intertidal ponds of messina's beachrock faunal assemblage, evaluation of ecosystem dynamics and communities' interactions. AAPP Accad. Pelorit. Pericol. Cl. Sci. Fis. Mat. Nat. 2018, 96, A41-A416. [CrossRef] 
7. Pérez-Ruzafa, A.; Pérez-Ruzafa, I.M.; Newton, A.; Marcos, C. Coastal Lagoons: Environmental Variability, Ecosystem Complexity, and Goods and Services Uniformity. In Coasts and Estuaries: The Future; Elsevier: Amsterdam, The Netherlands, 2019; pp. 253-276. ISBN 9780128140048.

8. Costanza, R. Valuing natural capital and ecosystem services toward the goals of efficiency, fairness, and sustainability. Ecosyst. Serv. 2020, 43, 101096. [CrossRef]

9. Bas-Silvestre, M.; Quintana, X.D.; Compte, J.; Gascón, S.; Boix, D.; Antón-Pardo, M.; Obrador, B. Ecosystem metabolism dynamics and environmental drivers in Mediterranean confined coastal lagoons. Estuar. Coast. Shelf Sci. 2020, 245, 106989. [CrossRef]

10. Savoca, S.; Grifó, G.; Panarello, G.; Albano, M.; Giacobbe, S.; Capillo, G.; Spanó, N.; Consolo, G. Modelling prey-predator interactions in Messina beachrock pools. Ecol. Modell. 2020, 434, 109206. [CrossRef]

11. Rivera, C.; Quiroga, E.; Meza, V.; Pastene, M. Evaluation of water quality and heavy metal concentrations in the RAMSAR Wetland El Yali (Central Chile, 3345" S). Mar. Pollut. Bull. 2019, 145, 499-507. [CrossRef] [PubMed]

12. Silvestro, S.; Capillo, G.; Sanfilippo, M.; Fiorino, E.; Giangrosso, G.; Ferrantelli, V.; Dara, S.; Vazzana, I.; Faggio, C. Appraisal of the abiotic and biotic framework of Faro Lake (Messina, Sicily). J. Biol. Res. 2017, 90, 14.

13. Metzger, E.; Simonucci, C.; Viollier, E.; Sarazin, G.; Prévot, F.; Jézéquel, D. Benthic response to shellfish farming in Thau lagoon: Pore water signature. Estuar. Coast. Shelf Sci. 2007, 72, 406-419. [CrossRef]

14. Xia, X.; Dong, J.; Wang, M.; Xie, H.; Xia, N.; Li, H.; Zhang, X.; Mou, X.; Wen, J.; Bao, Y. Effect of water-sediment regulation of the Xiaolangdi reservoir on the concentrations, characteristics, and fluxes of suspended sediment and organic carbon in the Yellow River. Sci. Total Environ. 2016, 571, 487-497. [CrossRef]

15. Gordeev, V.V.; Kravchishina, M.D. River flux of dissolved organic carbon (DOC) and particulate organic carbon (POC) to the Arctic Ocean: What are the consequences of the global changes? In Influence of Climate Change on the Changing Arctic and Sub-Arctic Conditions; Springer: Dordrecht, The Netherlands, 2009; ISBN 978-1-4020-9458-3.

16. Wei, X.; Hayes, D.J.; Fernandez, I.; Zhao, J.; Fraver, S.; Chan, C.; Diao, J. Identifying Key Environmental Factors Explaining Temporal Patterns of DOC Export from Watersheds in the Conterminous United States. J. Geophys. Res. Biogeosci. 2021, 126. [CrossRef]

17. Wei, X.; Hayes, D.J.; Fernandez, I. Fire reduces riverine DOC concentration draining a watershed and alters post-fire DOC recovery patterns. Environ. Res. Lett. 2021, 16, 024022. [CrossRef]

18. Lajtha, K.; Jones, J. Forest harvest legacies control dissolved organic carbon export in small watersheds, western Oregon. Biogeochemistry 2018, 140, 299-315. [CrossRef]

19. Ray, R.; Michaud, E.; Aller, R.C.; Vantrepotte, V.; Gleixner, G.; Walcker, R.; Devesa, J.; Le Goff, M.; Morvan, S.; Thouzeau, G. The sources and distribution of carbon (DOC, POC, DIC) in a mangrove dominated estuary (French Guiana, South America). Biogeochemistry 2018, 138, 297-321. [CrossRef]

20. St. Pierre, K.A.; Oliver, A.A.; Tank, S.E.; Hunt, B.P.V.; Giesbrecht, I.; Kellogg, C.T.E.; Jackson, J.M.; Lertzman, K.P.; Floyd, W.C.; Korver, M.C. Terrestrial exports of dissolved and particulate organic carbon affect nearshore ecosystems of the Pacific coastal temperate rainforest. Limnol. Oceanogr. 2020, 65, 2657-2675. [CrossRef]

21. Tsang, C.H.A.; Li, K.; Zeng, Y.; Zhao, W.; Zhang, T.; Zhan, Y.; Xie, R.; Leung, D.Y.C.; Huang, H. Titanium oxide based photocatalytic materials development and their role of in the air pollutants degradation: Overview and forecast. Environ. Int. 2019, 125, 200-228. [CrossRef]

22. St-Laurent, P.; Friedrichs, M.A.M.; Najjar, R.G.; Shadwick, E.H.; Tian, H.; Yao, Y. Relative impacts of global changes and regional watershed changes on the inorganic carbon balance of the Chesapeake Bay. Biogeosciences 2020, 17, 3779-3796. [CrossRef]

23. Halsey, K.H.; Giovannoni, S.J.; Graus, M.; Zhao, Y.; Landry, Z.; Thrash, J.C.; Vergin, K.L.; de Gouw, J. Biological cycling of volatile organic carbon by phytoplankton and bacterioplankton. Limnol. Oceanogr. 2017, 62, 2650-2661. [CrossRef]

24. Toyoda, J.G.; Goldman, A.; Chu, R.; Danczak, R.; Daly, R.; Garayburu-Caruso, V.A.; Graham, E.B.; Xinming, L.; Moran, J.J.; Huiying, R.; et al. WHONDRS Summer 2019 Sampling Campaign: Global River Corridor Sediment FTICR-MS, NPOC, and Aerobic Respiration; U.S. Department of Energy, Office of Scientifical and Technical Informations: Washington, DC, USA, 2020. [CrossRef]

25. Painter, S.C.; Lapworth, D.J.; Woodward, E.M.S.; Kroeger, S.; Evans, C.D.; Mayor, D.J.; Sanders, R.J. Terrestrial dissolved organic matter distribution in the North Sea. Sci. Total Environ. 2018, 630, 630-647. [CrossRef] [PubMed]

26. Vaughan, M.C.H.; Bowden, W.B.; Shanley, J.B.; Vermilyea, A.; Sleeper, R.; Gold, A.J.; Pradhanang, S.M.; Inamdar, S.P.; Levia, D.F.; Andres, A.S.; et al. High-frequency dissolved organic carbon and nitrate measurements reveal differences in storm hysteresis and loading in relation to land cover and seasonality. Water Resour. Res. 2017, 53, 5345-5363. [CrossRef]

27. Manganaro, A.; Pulicanò, G.; Sanfilippo, M. Temporal evolution of the area of Capo Peloro (Sicily, Italy) from pristine site into urbanized area. Transit. Waters Bull. 2011, 5, 23-31. [CrossRef]

28. Capillo, G.; Silvestro, S.; Sanfilippo, M.; Fiorino, E.; Giangrosso, G.; Ferrantelli, V.; Vazzana, I.; Faggio, C. Assessment of Electrolytes and Metals Profile of the Faro Lake (Capo Peloro Lagoon, Sicily, Italy) and Its Impact on Mytilus galloprovincialis. Chem. Biodivers. 2018, 15, e1800044. [CrossRef] [PubMed]

29. Bottari, A.; Bottari, C.; Carveni, P.; Giacobbe, S.; Spanò, N. Genesis and geomorphologic and ecological evolution of the Ganzirri salt marsh (Messina, Italy). Quat. Int. 2005, 140-141, 150-158. [CrossRef]

30. Vanucci, S.; Bruni, V.; Pulicanò, G. Spatial and temporal distribution of virioplankton and bacterioplankton in a Brackish Environment (Lake of Ganzirri, Italy). Hydrobiologia 2005, 539, 83-92. [CrossRef]

31. Giuffrè, G. Le Diatomee Planctoniche Del Sistema Lagunare Di Capo Peloro (Messina, Sicilia) E La Successione Annuale Del Fitoplancton in Rapporto Con I Parametri Fisico-Chimici Nel Pantano Di Ganzirri. Nat. Sicil. 2011, 35, 187-214. 
32. Magazzu, G.; Decembrini, F. Primary production, biomass and abundance of phototrophic picoplankton in the Mediterranean Sea: A review. Aquat. Microb. Ecol. 1995, 9, 97-104. [CrossRef]

33. Licata, P.; Di Bella, G.; Dugo, G.; Naccari, F. Organochlorine pesticides, PCBs and heavy metals in tissues of the mullet Liza aurata in lake Ganzirri and Straits of Messina (Sicily, Italy). Chemosphere 2003, 52, 231-238. [CrossRef]

34. Rinaldi, A.; Montalto, V.; Manganaro, A.; Mazzola, A.; Mirto, S.; Sanfilippo, M.; Sarà, G. Predictive mechanistic bioenergetics to model habitat suitability ofshellfish culture in coastal lakes. Estuar. Coast. Shelf Sci. 2014, 144, 89-98. [CrossRef]

35. Manganaro, A.; Pulicanò, G.; Reale, A.; Sanfilippo, M.; Sarà, G. Filtration pressure by bivalves affects the trophic conditions in Mediterranean shallow ecosystems. Chem. Ecol. 2009, 25, 467-478. [CrossRef]

36. Raffa, C.; Rizzo, C.; Strous, M.; De Domenico, E.; Sanfilippo, M.; Michaud, L.; Lo Giudice, A. Prokaryotic dynamics in the meromictic coastal Lake Faro (Sicily, Italy). Diversity 2019, 11, 37. [CrossRef]

37. Andrisoa, A.; Stieglitz, T.C.; Rodellas, V.; Raimbault, P. Primary production in coastal lagoons supported by groundwater discharge and porewater fluxes inferred from nitrogen and carbon isotope signatures. Mar. Chem. 2019, 210, 48-60. [CrossRef]

38. Anufriieva, E.; Shadrin, N. The long-term changes in plankton composition: Is Bay Sivash transforming back into one of the world's largest habitats of Artemia sp. (Crustacea, Anostraca)? Aquac. Res. 2020, 51, 341-350. [CrossRef]

39. Pérez-Ruzafa, A.; Hegazi, M.I.; Pérez-Ruzafa, I.M.; Marcos, C. Differences in spatial and seasonal patterns of macrophyte assemblages between a coastal lagoon and the open sea. Mar. Environ. Res. 2008, 65, 291-314. [CrossRef] [PubMed]

40. Costa-Pierce, B.A. Sustainable ecological aquaculture systems: The need for a new social contract for aquaculture development. Mar. Technol. Soc. J. 2010, 44, 88-112. [CrossRef]

41. Petersen, C.; Costa-Pierce, B.; Dumbauld, B. Ecosystem Concepts for Sustainable Bivalve Mariculture; The National Academies Press: Washington, DC, USA, 2010; pp. 1-190. [CrossRef]

42. D'Iglio, C.; Natale, S.; Albano, M.; Savoca, S.; Famulari, S.; Gervasi, C.; Lanteri, G.; Panarello, G.; Spanò, N.; Capillo, G. Otolith Analyses Highlight Morpho-Functional Differences of Three Species of Mullet (Mugilidae) from Transitional Water. Sustainability 2022, 14, 398. [CrossRef]

43. D’Iglio, C.; Albano, M.; Famulari, S.; Savoca, S.; Panarello, G.; Di Paola, D.; Perdichizzi, A.; Rinelli, P.; Lanteri, G.; Spanò, N.; et al. Intra- and interspecific variability among congeneric Pagellus otoliths. Sci. Rep. 2021, 11, 16315. [CrossRef]

44. D'iglio, C.; Albano, M.; Tiralongo, F.; Famulari, S.; Rinelli, P.; Savoca, S.; Spanò, N.; Capillo, G. Biological and ecological aspects of the blackmouth catshark (Galeus melastomus rafinesque, 1810) in the southern tyrrhenian sea. J. Mar. Sci. Eng. 2021, 9, 967. [CrossRef]

45. Mazzola, A.; Bergamasco, A.; Calvo, S.; Caruso, G.; Chemello, R.; Colombo, F.; Giaccone, G.; Gianguzza, P.; Guglielmo, L.; Leonardi, M.; et al. Sicilian transitional waters: Current status and future development. Chem. Ecol. 2010, 26, 267-283. [CrossRef]

46. Sanfilippo, M. La Componente Organica del Seston nel Lago di Ganzirri: Qualità e Valore Nutrizionale Come Risorsa Ambientale. Ph.D. Thesis, University of Messina, Messina, Italy, 2000.

47. Albano, M.; Panarello, G.; Di Paola, D.; D’Angelo, G.; Granata, A.; Savoca, S.; Capillo, G. The mauve stinger Pelagia noctiluca (Cnidaria, Scyphozoa) plastics contamination, the Strait of Messina case. Int. J. Environ. Stud. 2021, 78, 977-982. [CrossRef]

48. Butman, D.; Raymond, P.A. Significant efflux of carbon dioxide from streams and rivers in the United States. Nat. Geosci. 2011, 4, 839-842. [CrossRef]

49. Giordani, G.; Viaroli, P.; Swaney, D.P.; Murray, N.C. Nutrient fluxes in transitional zones of the Italian coast. Loicz RES 2005, 28, 103-110.

50. Sanfilippo, M.; Capillo, G.; Spanò, N.; Manganaro, A. Evaluation of water variables in no-take zone of ustica marine protected area (Southern Tyrrhenian Sea). Braz. Arch. Biol. Technol. 2016, 59. [CrossRef]

51. APAT; IRSA-CNR. Metodi Analitici per le Acque; APAT: Rome, Italy, 2004.

52. Montalto, V.; Martinez, M.; Rinaldi, A.; Sarà, G.; Mirto, S. The effect of the quality of diet on the functional response of Mytilus galloprovincialis (Lamarck, 1819): Implications for integrated multitrophic aquaculture (IMTA) and marine spatial planning. Aquaculture 2017, 468, 371-377. [CrossRef]

53. Directive 2000/60/EC European Parliament and Council of 23rd October 2000 establishing a framework for community action in the field of water policy. Off. J. Eur. Commun. 2000. Available online: http:/ / eur-lex.europa.eu/LexUriServ/LexUriServ.do?uri= CELEX:32000L0060:en:NOT (accessed on 20 November 2014).

54. Poikane, S.; Kelly, M.G.; Salas Herrero, F.; Pitt, J.A.; Jarvie, H.P.; Claussen, U.; Leujak, W.; Lyche Solheim, A.; Teixeira, H.; Phillips, G. Nutrient criteria for surface waters under the European Water Framework Directive: Current state-of-the-art, challenges and future outlook. Sci. Total Environ. 2019, 695, 133888. [CrossRef] [PubMed]

55. Elliott, M.; Day, J.W.; Ramachandran, R.; Wolanski, E.; Fang, Q.; Sheehan, M.R.; Seen, A.J.; Ellison, J.C. A Synthesis: What Is the Future for Coasts, Estuaries, Deltas and Other Transitional Habitats in 2050 and Beyond? Coasts Estuaries Futur. 2019, 1-28. [CrossRef]

56. Orro, C.; Cabana, D. Seasonal implications of the benthic ecological status assessment in a protected Mediterranean coastal lagoon: Stagno Longu of Posada (Sardinia, Italy). Reg. Stud. Mar. Sci. 2021, 44, 101759. [CrossRef]

57. Leonardi, M.; Bergamasco, A.; Giacobbe, S.; Azzaro, F.; Cosentino, A.; Crupi, A.; Lanza, S.; Randazzo, G.; Crisafi, E. A four decades multiparametric investigation in a Mediterranean dynamic ecosystem: Mollusc assemblages answer to the environmental changes. Estuar. Coast. Shelf Sci. 2020, 234, 106625. [CrossRef] 
58. Lopez-Gonzalez, P.J.; Guerrero, F.; Castro, M.C. Seasonal fluctuations in the plankton community in a hypersaline temporary lake (Honda, southern Spain). Int. J. Salt Lake Res. 1997, 6, 353-371. [CrossRef]

59. Renzi, M.; Provenza, F.; Pignattelli, S.; Cilenti, L.; Specchiulli, A.; Pepi, M. Mediterranean coastal lagoons: The importance of monitoring in sediments the biochemical composition of organic matter. Int. J. Environ. Res. Public Health 2019, 16, 3466. [CrossRef] [PubMed]

60. Gjoni, V.; Ghinis, S.; Pinna, M.; Mazzotta, L.; Marini, G.; Ciotti, M.; Rosati, I.; Vignes, F.; Arima, S.; Basset, A. Patterns of functional diversity of macroinvertebrates across three aquatic ecosystem types, NE mediterranean. Mediterr. Mar. Sci. 2019, 20, 703-717. [CrossRef]

61. Crossman, N.D.; Burkhard, B.; Nedkov, S. Quantifying and mapping ecosystem services. Int. J. Biodivers. Sci. Ecosyst. Serv. Manag. 2012, 8, 1-4. [CrossRef]

62. Maisano, M.; Natalotto, A.; Cappello, T.; Giannetto, A.; Oliva, S.; Parrino, V.; Sanfilippo, M.; Mauceri, A. Influences of Environmental Variables on Neurotransmission, Oxidative System, and Hypoxia Signaling on Two Clam Species from a Mediterranean Coastal Lagoon. J. Shellfish Res. 2016, 35, 41-49. [CrossRef]

63. Spanò, N.; Di Paola, D.; Albano, M.; Manganaro, A.; Sanfilippo, M.; D’Iglio, C.; Capillo, G.; Savoca, S. Growth performance and bioremediation potential of Gracilaria gracilis (Steentoft, L.M. Irvine \& Farnham, 1995). Int. J. Environ. Stud. 2021, 1-13. [CrossRef]

64. Giacobbe, S.; Caltabiano, M.; Puglisi, M. The Pelorias shell in the ancient coins: Taxonomic attribution and implication in the management of Capo Peloro and Laghi di Ganzirri CSI. Biol. Mar. Mediterr. 2009, 16, 134-135.

65. Capillo, G.; Sanfilippo, M.; Li Volsi, R.; Spinelli, A.; Panarello, G.; Spanò, N. Gracilaria gracilis (gracilariales, rhodotphyta) from Ganzirri lagoon, state of art and perspectives. In Proceedings of the XIII Incontro dei Dottorandi in Ecologia e Scienze dei Sistemi Acquatici, Palermo, Italy, 3-5 March 2017.

66. Shadrin, N.; Kolesnikova, E.; Revkova, T.; Latushkin, A.; Chepyzhenko, A.; Dyakov, N.; Anufriieva, E. Macrostructure of benthos along a salinity gradient: The case of Sivash Bay (the Sea of Azov), the largest hypersaline lagoon worldwide. J. Sea Res. 2019, 154, 101811. [CrossRef]

67. Yan, D.; Endo, H.; Suzuki, K. Increased temperature benefits growth and photosynthetic performance of the sea ice diatom Nitzschia cf. neglecta (Bacillariophyceae) isolated from saroma lagoon, Hokkaido, Japan. J. Phycol. 2019, 55, 700-713. [CrossRef]

68. Kjerfve, B. Coastal Lagoons; Elsevier: Amsterdam, The Netherlands, 1994.

69. Behera, P.; Mahapatra, S.; Mohapatra, M.; Kim, J.Y.; Adhya, T.K.; Raina, V.; Suar, M.; Pattnaik, A.K.; Rastogi, G. Salinity and macrophyte drive the biogeography of the sedimentary bacterial communities in a brackish water tropical coastal lagoon. Sci. Total Environ. 2017, 595, 472-485. [CrossRef]

70. Telesh, I.V.; Khlebovich, V.V. Principal processes within the estuarine salinity gradient: A review. Mar. Pollut. Bull. 2010, 61, 149-155. [CrossRef] [PubMed]

71. Mogaddam, S.F.; Bidokhti, A.A.; Givi, F.A.; Ezam, M. Evaluation of physical changes (temperature and salinity) in the Persian Gulf waters due to climate change using field data and numerical modeling. Int. J. Environ. Sci. Technol. 2020, 17, 2141-2152. [CrossRef]

72. Corredor, J.E.; Morell, J.M. Seasonal variation of physical and biogeochemical features in eastern Caribbean Surface Water. J. Geophys. Res. Ocean. 2001, 106, 4517-4525. [CrossRef]

73. Czuba, J.A.; David, S.R.; Edmonds, D.A.; Ward, A.S. Dynamics of Surface-Water Connectivity in a Low-Gradient Meandering River Floodplain. Water Resour. Res. 2019, 55, 1849-1870. [CrossRef]

74. Panigrahi, S.; Wikner, J.; Panigrahy, R.C.; Satapathy, K.K.; Acharya, B.C. Variability of nutrients and phytoplankton biomass in a shallow brackish water ecosystem (Chilika Lagoon, India). Limnology 2009, 10, 73-85. [CrossRef]

75. Nizzoli, D.; Welsh, D.T.; Bartoli, M.; Viaroli, P. Impacts of mussel (Mytilus galloprovincialis) farming on oxygen consumption and nutrient recycling in a eutrophic coastal lagoon. Hydrobiologia 2005, 550, 183-198. [CrossRef]

76. Newell, R.I.E. Ecosystem influences of natural and cultivated populations of suspension-feeding bivalve molluscs: A review. J. Shellfish Res. 2004, 23, 51-61.

77. Sullivan, T.; Byrne, C.; Harman, L.; Davenport, J.; McAllen, R.; Regan, F. Determination of spatial and temporal variability of pH and dissolved oxygen concentrations in a seasonally hypoxic semi-enclosed marine basin using continuous monitoring. Anal. Methods 2014, 6, 5489-5497. [CrossRef]

78. Feely, R.A.; Alin, S.R.; Newton, J.; Sabine, C.L.; Warner, M.; Devol, A.; Krembs, C.; Maloy, C. The combined effects of ocean acidification, mixing, and respiration on $\mathrm{pH}$ and carbonate saturation in an urbanized estuary. Estuar. Coast. Shelf Sci. 2010, 88, 442-449. [CrossRef]

79. Rodhouse, P.; Roden, C. Carbon budget for a coastal inlet in relation to intensive cultivation of suspension-feeding bivalve mollusks. Mar. Ecol. Prog. Ser. 1987, 36, 225-236. [CrossRef]

80. Sarà, G.; Mazzola, A. The carrying capacity for Mediterranean bivalve suspension feeders: Evidence from analysis of food availability and hydrodynamics and their integration into a local model. Ecol. Modell. 2004, 179, 281-296. [CrossRef]

81. Capillo, G.; Savoca, S.; Costa, R.; Sanfilippo, M.; Rizzo, C.; Giudice, A.L.; Albergamo, A.; Rando, R.; Bartolomeo, G.; Spanò, N.; et al. New insights into the culture method and antibacterial potential of gracilaria gracilis. Mar. Drugs 2018, 16, 492. [CrossRef] [PubMed]

82. Capillo, G.; Genovese, G.; Monteleone, A.; Morabito, M.; Sanfilippo, M.M.A. From culture to application. Agar from Gracilaria gracilis of Ganzirri Lagoon (Sicily, Italy). J. Biol. Res. 2014, 87, 5-6. 
83. Buapet, P.; Gullström, M.; Björk, M. Photosynthetic activity of seagrasses and macroalgae in temperate shallow waters can alter seawater $\mathrm{pH}$ and total inorganic carbon content at the scale of a coastal embayment. Mar. Freshw. Res. 2013, 64, 1040-1048. [CrossRef]

84. Grangeré, K.; Lefebvre, S.; Bacher, C.; Cugier, P.; Ménesguen, A. Modelling the spatial heterogeneity of ecological processes in an intertidal estuarine bay: Dynamic interactions between bivalves and phytoplankton. Mar. Ecol. Prog. Ser. 2010, 415, 141-158. [CrossRef]

85. Agawin, N.S.R.; Duarte, C.M.; Agustí, S. Nutrient and temperature control of the contribution of picoplankton to phytoplankton biomass and production. Limnol. Oceanogr. 2000, 45, 591-600. [CrossRef]

86. Coelho, S.; Gamito, S.; Pérez-Ruzafa, A. Trophic state of Foz de Almargem coastal lagoon (Algarve, South Portugal) based on the water quality and the phytoplankton community. Estuar. Coast. Shelf Sci. 2007, 71, 218-231. [CrossRef]

87. Froján, M.; Arbones, B.; Zúñiga, D.; Castro, C.G.; Figueiras, F.G. Microbial plankton community in the Ría de Vigo (NW Iberian upwelling system): Impact of the culture of Mytilus galloprovincialis. Mar. Ecol. Prog. Ser. 2014, 498, 43-54. [CrossRef]

88. Fazio, F.; Saoca, C.; Sanfilippo, M.; Capillo, G.; Spanò, N.; Piccione, G. Response of vanadium bioaccumulation in tissues of Mugil cephalus (Linnaeus 1758). Sci. Total Environ. 2019, 689, 774-780. [CrossRef]

89. Fazio, F.; Faggio, C.; Marafioti, S.; Torre, A.; Sanfilippo, M.; Piccione, G. Effect of water quality on hematological and biochemical parameters of Gobius niger caught in Faro lake (Sicily). Iran. J. Fish. Sci. 2013, 12, 219-231.

90. Parrino, V.; Cappello, T.; Costa, G.; Cannavà, C.; Sanfilippo, M.; Fazio, F.; Fasulo, S. Comparative study of haematology of two teleost fish (Mugil cephalus and Carassius auratus) from different environments and feeding habits. Eur. Zool. J. 2018, 85, 194-200. [CrossRef]

91. Pagano, M.; Capillo, G.; Sanfilippo, M.; Palato, S.; Trischitta, F.; Manganaro, A.; Faggio, C. Evaluation of functionality and biological responses of mytilus galloprovincialis after exposure to quaternium-15 (Methenamine 3-Chloroallylochloride). Molecules 2016, 21, 144. [CrossRef]

92. Messina, C.M.; Faggio, C.; Laudicella, V.A.; Sanfilippo, M.; Trischitta, F.; Santulli, A. Effect of sodium dodecyl sulfate (SDS) on stress response in the Mediterranean mussel (Mytilus galloprovincialis): Regulatory volume decrease (Rvd) and modulation of biochemical markers related to oxidative stress. Aquat. Toxicol. 2014, 157, 94-100. [CrossRef] [PubMed]

93. Stara, A.; Pagano, M.; Capillo, G.; Fabrello, J.; Sandova, M.; Albano, M.; Zuskova, E.; Velisek, J.; Matozzo, V.; Faggio, C. Acute effects of neonicotinoid insecticides on Mytilus galloprovincialis: A case study with the active compound thiacloprid and the commercial formulation calypso 480 SC. Ecotoxicol. Environ. Saf. 2020, 203, 110980. [CrossRef]

94. Stara, A.; Pagano, M.; Albano, M.; Savoca, S.; Di Bella, G.; Albergamo, A.; Koutkova, Z.; Sandova, M.; Velisek, J.; Fabrello, J.; et al. Effects of long-term exposure of Mytilus galloprovincialis to thiacloprid: A multibiomarker approach. Environ. Pollut. 2021, 289, 117892. [CrossRef] [PubMed] 